\title{
OS FRAGMENTOS DE ARTÁPANO: INTRODUÇÃO E TRADUÇÃO
}

RESUMO: Artápano é personagem consideravelmente inusitado da tradição judaica, justamente por quase completamente desconhecido e não ser unanimemente considerado judeu. Sua obra, contudo, da qual nos restam somente três trechos, deixa vestígios sobre seu projeto literário e o liga inevitavelmente à história das narrativas bíblicas, uma vez que consiste em uma ampliação (e transformação) criativa dos relatos de Gênesis e Exxodo sobre as vidas de "heróis" hebreus. Esses três trechos são apresentados aqui em uma tradução anotada, que é antecedida por uma introdução, na qual se discutem brevemente questôes importantes para uma leitura informada desses fragmentos.

PALAVRAS-CHAVE: Artápano; Judaísmo; reescrita da Bíblia.

\section{THE EXCERPTS OF ARTAPANUS: INTRODUCTION AND TRANSLATION}

\begin{abstract}
Artapanus is a considerably peculiar character of the Jewish tradition, since he is almost completely unknown and not unanimously taken as a Jew. His works, of which only three excerpts arrived to our time, however, let leads of his literary project and unavoidably connects him to the history of biblical narratives, because it consists in an creative amplification (and transformation) of the accounts of Genesis and Exodus on the Hebrew heroes' lives. These three excerpts are presented here in a translation with notes, which is preceded by an introduction, in which important questions are briefly discussed in order to promote an informed reading.
\end{abstract}

KEYWORDS: Artapanus, Judaism; rewritten Bible.

* Doutor em Literaturas Clássicas e Medievais (UFMG), realiza atualmente pós-doutorado junto ao grupo de pesquisa em Filosofia Antiga da UFMG. O presente trabalho foi realizado com apoio do $\mathrm{CNPq}$, Conselho Nacional de Desenvolvimento Científico e Tecnológico Brasil. 


\section{INTRODUÇÃO}

1. Daniel Barbu afirma que "não é impossível pensar que as citaçôes feitas ali [em Eusébio/ Poliístor] sejam de fato representativas do conteúdo e da estrutura da obra da qual foram tiradas" (BARBU: 2009, 11).

Como o conjunto de citaçōes apresenta um trecho menor para Abraão, outro um pouco maior para

José e um visivelmente mais amplo para Moisés, de forma crescente conforme a cronologia da narrativa canônica, Barbu sugere que a obra de

Artápano se trataria de uma forma de Vita Mosis (vida de Moisés), e que os eventos anteriores só figurariam como preparação para a narrativa da história do legislador. De minha parte, embora reconheça que "não é impossível” essa relação direta entre citaçōes e texto fonte citado, ressalto que é incerta, e que conclusóes tiradas a partir de tal hipótese deveriam permanecer como possibilidade de reconstrução e não como pretensa descrição da obra perdida.
$\mathrm{O}$ s fragmentos de Artápano que nos chegaram e que figuram traduzidos aqui foram preservados sobretudo na obra de Eusébio de Cesareia, que os toma, por sua vez, de Alexandre Poliístor. São três pequenos trechos dedicados respectivamente a Abraão (Praep. Evang. 9.18.1), José (Praep. Evang. 9.23.1-4) e Moisés (Praep. Evang. 9.27.1-37). O último deles, referente ao legislador dos judeus, tem uma pequena parte conservada também por Clemente de Alexandria (Stromata 1.23.154.2-3).

Não é surpreendente que um texto preservado dessa forma, em pequenas porções e em terceira mão, suscite mais hipóteses que certezas a respeito de suas origens. Além da precária transmissão, outras peculiaridades do texto intrigam: são fragmentos relacionados com a tradição literária judaica, que se referem a eventos acontecimentos que têm o Egito como palco, e escritos por um enigmático autor de nome persa. $\mathrm{O}$ fato é que não temos qualquer informação sobre o autor ou sobre as características de sua obra como um todo, nada além dos próprios fragmentos que nos chegaram como seus.

O primeiro desses fragmentos é referido por Eusébio

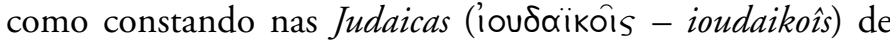
Artápano, enquanto os dois seguintes são de Sobre os Judeus

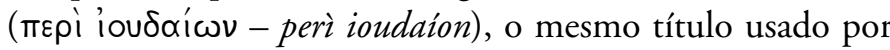
Clemente para o trecho que conserva. Não obstante, o conteúdo leva a pensar que os três fragmentos sejam parte de uma única obra, que trataria de diferentes personagens da história judaica, com ênfase sobre Moisés (BARBU: 2009, 11). ${ }^{1}$ Essa ênfase é sugerida pelo volume da narrativa sobre Moisés preservada por Eusébio e, possivelmente, Alexandre Poliístor. Certamente, contudo, essa diferença quantitativa pode ter sido (em alguma medida) fruto da seleção dos transmissores, e não (somente) da composição do autor.

Esse autor, como assinalei, tem nome persa. Afirmase que seria do Egito, justamente por referir-se somente aos acontecimentos relacionados com tal região, como se tivesse selecionado da história judaica e da vida dos 
patriarcas somente o que teria relação direta com seu lugar de residência e de seu público leitor imediato. Por isso Abraão e José figurariam em sua obra, mas não Jacó, que pouca relação tem com as terras do Nilo. Mais uma vez, observo que não me parece seguro deduzir a estrutura completa da obra com base no pouco que temos. As intervenções de Alexandre e Eusébio podem ter sido decisivas em muitos aspectos. Ainda assim, Artápano tem sido reconhecido como habitante do Egito, ou, mais precisamente, como um judeu helenístico habitante dessa região. Inclusive, as modificações que realiza na narrativa canônica não seriam feitas de modo impensado mas com o objetivo único de "prover um contexto histórico para a vida dos judeus no Egito, reforçando sua posição e status ali” (JOHNSON: 2004, 99).

Se a localização geográfica do autor se deve a um (suposto) recorte topológico de sua narrativa, sua inserção no âmbito dos escritores judeus helenísticos, um quase consenso desde o século XIX, se dá pelo fato de se dedicar a contar a história de personagens da tradição literária judaica, expondo seus feitos de modo positivo. Em linhas gerais, a lógica se resume no fato de que se um escritor fala dos judeus, dependendo ainda que em parte da tradição "bíblica" e sem motivação antissemita, ele deve ser judeu. Já o motivo que levava muitos leitores a recusarem a inscrição de Artápano no rol dos judeus reside no fato de que, embora promova uma visão vitoriosa dos patriarcas judeus, seu texto os associa a práticas religiosas não-judaicas e trata o politeísmo de modo pouco crítico. Em linhas gerais, então, um autor não é visto como judeu se não segue uma certa ortodoxia judaica. Em princípio, o problema persiste, porque essa ortodoxia não necessariamente era imperativa no entorno cultural mais próximo de Artápano no tempo em que produziu sua obra. Todavia, não deixa de ser significativa a falta de paralelo em textos de outros escritores judeus helenísticos que chegaram a nosso tempo. Nenhum outro autor apresenta orgulhosamente o legislador do judaísmo - a religião monoteísta (e desprovida de imagens) daqueles tempos - como instaurador do culto de animais no Egito. ${ }^{2}$
2. Uma tentativa de explicação para essa excentricidade do texto de Artápano se embasa na consideração de um contexto apologético para a obra. Artápano estaria se contrapondo a acusações de desrespeito para com os deuses (e até mesmo ateísmo) frequentemente levantadas contra os judeus. Ao estabelecer Moisés como instaurador do cultos aos animais sagrados no Egito, ele desfaria tal acusação (cf. JACOBSON: 2006, 215). Contudo, ainda que essa suposta finalidade apologética seja capaz de suscitar uma harmonia teleológica, a estranheza diante da radicalidade da estratégia arquitetada pelo autor, se considerado judeu, permaneceria por sua remarcada peculiaridade. Collins procura demonstrar que a apreciação de Artápano do culto aos animais não é simples, uma vez que ele apresenta tais deuses como inventados por Moisés, enquanto "não compromete a superioridade do Deus dos judeus" (COLLINS: 1985, 893). Todavia, se a superioridade não é comprometida, a unicidade da divindade e a exclusividade de culto (cf. Dt 4:16ss; Dt 6:4) são certamente abaladas. 
3. Em Fílon de Alexandria, escritor judeu helenístico que nos legou considerável volume de textos, por exemplo, o culto aos animais é criticado como mais absurdo que as também criticáveis outras formas de politeísmo, uma vez que continha um paradoxo intragável: seres civilizados cultuando incivilizados, racionais cultuando irracionais, líderes, os subalternos (Cont. 9). Em outro trecho, reconhece como natural que os egípcios aceitassem a divinização de seres humanos, por cultuarem até mesmo animais (Legat. 138139). A atribuiçāo do título de "deus" a animais revela o pouco valor que os egípcios dão ao mesmo (Legat. 164).
Pelo contrário, é comum encontrar críticas ferrenhas a esse tipo de culto. ${ }^{3}$

Então, embora reconheça como em alguma medida possivel a atual tendência de reconhecer Artápano como judeu, concordo com as ressalvas de Howard Jacobson (JACOBSON: 2006), que colocou novamente em questão a certeza sobre a identidade judaica do autor. Quanto à apresentação positiva de feitos de heróis judaicos, ele observa:

Havia vários "filo-semitas" (por assim dizer) no mundo grecoromano. Nós deveríamos esperar que um filósofo grego insinuasse que o grande Platão era de fato devedor de Moisés? Numênio o fez. Em resumo, uma obra de admiração e louvor a um povo é dificilmente um argumento para o pertencimento do autor a tal povo. E, ainda, esse é o único argumento que pesquisadores realmente usam para sustentar que Artápano era um judeu. (JACOBSON: 2006, 218.)

Quanto à época da produção do texto, ao menos um terminus ante quem nós temos ao certo. Artápano precisa ter escrito antes de Alexandre Poliístor para ter sido citado por ele. Ou seja, na segunda metade do século I a.C., a obra de Artápano já circulava e estava disponível a Alexandre, um investigador não-judeu, interessado, entre tantos outros assuntos, na história judaica. Quanto ao terminus post quem, há mais dificuldades. Certas semelhanças lexicais entre o texto dos fragmentos e o da Septuaginta sugerem, em princípio, que Artápano teria utilizado essa tradução da Torah, tradicionalmente atribuída ao período de Ptolomeu II Filadelfo (309 - 246 a.C.), como fonte de sua narrativa. Mas há também diferenças consideráveis entre seu texto e o da LXX, além da possibilidade de que outras traduçōes do texto mosaico circulassem em grego antes da produção da tradução "oficial" que veio a ser conhecida como Septuaginta/LXX. Há, ainda, uma diversidade de hipóteses de localização temporal mais precisa para a obra, elaboradas a partir de uma suposta relação genética e de espelhamento entre o texto e determinados acontecimentos experimentados pelos judeus em reinados de diferentes Ptolomeus no Egito (cf. BARBU: 2009, 16-18; COLLINS: 1985, 890-891). Embora interessantes como exercícios intelectuais, parece-me que essas 
propostas não são verificáveis, nem se embasam em evidências suficientes a ponto de ultrapassarem o status de hipóteses (e mais: são hipóteses que tomam como pressupostos outras hipóteses improvadas, como a autoria judaica do texto).

O fato de pouco sabermos sobre as características da obra ou sobre o autor não torna desinteressante a leitura da narrativa. A bem da verdade, um elemento atrativo desses fragmentos é justamente o potencial que têm para suscitarem as mais diferentes leituras. Eles poderiam provir, como entende Jacobson, de um não-judeu interessado na tradição judaica e favorável aos judeus. Por outro lado, é considerável a já comum proposta de se ler Artápano como intelectual judeu envolvido na historiografia competitiva do período helenístico, escrevendo em oposição a Maneto ou outro historiador egípcio semelhante (COLLINS: 1985, 891-892). $\mathrm{O}$ autor poderia ser inclusive um judeu que se disfarça de não-judeu, no nome e na forma como se refere a práticas religiosas alheias, como queria E. W. Hengstenberger, com vistas a ser melhor considerado no contexto não-judaico (cf. BARBU: 2009, 6). Mas cobra atenção também a hipótese quase oposta de que o texto reflita o sincretismo da tradição religiosa praticada popularmente e não pensada por um intelectual a partir das tradições letradas (cf. BARBU: 2009, 20-23). E é igualmente mencionável a interpretação de Erich Gruen, que considera Artápano um judeu, porque, segundo ele, "nenhum gentio teria tido motivação para fazer isso [recontar e reescrever histórias bíblicas]" (GRUEN: 2004, 201), um pressuposto um tanto preconcebido e pouco desenvolvido. A diferença no tratamento dado por Gruen aos fragmentos, porém, está no fato de que ele considera que o conteúdo bíblico do texto impede a identidade não-judaica não somente do autor, mas também do público leitor almejado:

Quantos gentios consumiriam escritos de um judeu (mesmo um judeu que usa pseudônimo) que reproduziam ou amplificavam histórias bíblicas que recontavam as proezas dos patriarcas hebreus? Como propaganda, a narrativa ganharia poucos convertidos. Os leitores de Artápano eram, com toda probabilidade, judeus que gostavam de um bom conto. (GRUEN: 2004, 202)
4. Essa ideia de que não se podia esperar que gentios se dedicassem à leitura de obras relacionadas à tradição judaica não é consistente. Além de evidências literárias, inclusive arroladas por Jacobson no artigo supracitado, deve-se considerar que a existência de numerosas conversóes ao judaísmo na Antiguidade (FELDMAN: 2006) atesta a existência de um interesse dos não-judeus pela tradição judaica. Esse interesse, que resultava em conversões em muitos casos, em mais casos ainda resultaria em uma busca pelo conhecimento a respeito das origens daquela tradição. Os judeus, ainda que não fossem proselitistas, também não guardavam seus textos em segredo, mas informavam os que se aproximavam com curiosidade (cf. COHEN: 2010; ORRIEUX;WILL: 1992; DONALDSON: 2007).

Cabe observar que, depois da publicação do artigo de Jacobson, Erich Gruen volta a utilizar-se de Artápano como autor judeu. $\mathrm{Na}$ ocasião, reconhece certo valor no referido artigo, inclusive acatando o argumento de que a identidade judaica não é atestada simplesmente pela visão positiva dos judeus, mas refere-se ao trabalho criativo a partir das fontes escritas para concluir que "um público leitor culto e perspicaz para tal obra incluiria poucos gentios" (GRUEN: 2011, 326). Pois bem, seria essa quantidade reduzida de um público leitor real e realmente apto 
a ler um texto um parâmetro para a possibilidade de surgimento desse texto em determinado contexto na Antiguidade?

5. Considere-se também GRUEN: 2002, 160.

6. Como especulação, parece-me sensato imaginar que, ainda na Antiguidade, um leitor judeu informado teria duas possíveis reações a esse texto. Se o levasse a sério e fosse zeloso com sua tradição religiosa, provavelmente o acusaria de desvirtuado. Por outro lado, mesmo sabendo das variaçōes, poderia divertirse de modo semelhante ao de um leitor atual, que se entretém com adaptações de personagens históricos com elementos de diferentes épocas e dados deliberadamente fora de lugar. Se ao menos uma parte dos judeus não fosse capaz de se divertir com a história dos patriarcas contada de forma não tão precisa, obras como a Eksagogué de Ezequiel não seriam concebíveis.

7. O termo só aparece em Artápano, pelo que se supõe que ele o tenha cunhado.

8. A ida de Abraão ao Egito é narrada em Gn 12:10-20. O fato de ele ter ido ao Egito é praticamente a única concordância entre a narrativa canônica e a de Artápano. No mais, as histórias narradas não têm correlação, a não ser pelo fato de que em ambas o patriarca parece gozar do favor do governante egípcio. Contudo, no Gênesis o motivo do privilégio é um tanto reprovável: Abraão finge que sua esposa é sua irmã, de modo que o
Gruen, então, propõe que os fragmentos sejam lidos como fruto de um escritor criativo, dedicado à produção de contos sem qualquer pretensão apologética, séria ou historiográfica destinada a um embate com intelectuais nãojudeus, mas sim destinados ao prazer de leitores judeus, contendo aspectos fortemente jocosos inclusive. ${ }^{5}$

Ao leitor da presente tradução caberá discernir entre as diferentes possibilidades aquela que lhe parece mais razoável. Nas páginas que seguem, Abraão será professor de astrologia do Faraó, José solicitará ajuda dos Árabes para que o levem ao Egito (e não será vendido como escravo pelos irmãos, como em Gn 37:27-28), e Moisés será professor de Orfeu e chamado de Hermes pelos sacerdotes egípcios. Ainda que o texto em si não tenha sido composto com fins de deleite, como quer Gruen, ele certamente possibilita não somente uma leitura interessada em desvendar com exatidão ou razoabilidade seus dilemas, mas também uma apreciação diversa e (por que não?) divertida, pela degustação dos detalhes que oscilam entre semelhanças e diferenças, e passeiam entre diferentes tradições (a saber, grega, egípcia e judaica). ${ }^{6}$

\section{TRADUÇÃO}

Fragmento 1 (PRAEP. EVANG. 9.18.1)

1. Artápano diz nas Judaicas que os judeus eram chamados hermiuth, ${ }^{7}$ o que seria "judeus" traduzido para a língua helênica; mas que se chamaram hebreus a partir de Abraão. E diz que este foi ao Egito, ${ }^{8}$ para junto do rei dos egípcios, Farethothes, ${ }^{9}$ e lhe ensinou a astrologia. E que, tendo permanecido ali por vinte anos, partiu novamente para as regiōes da Síria. E que, dentre os que haviam ido com ele, muitos permaneceram no Egito por causa da prosperidade do país. ${ }^{10}$ 
1. Artápano diz em Sobre os Judeus que José era descendente de Abraão, filho de Jacó. Ao superar os outros em inteligência e entendimento, foi vítima de um plano tramado pelos irmãos. Tendo previsto o levante, pediu aos vizinhos árabes que o levassem ao Egito. Eles fizeram o solicitado, pois os reis dos árabes são descendentes de Israel, ${ }^{11}$ filhos de Abraão, irmãos de Isaque.

2. E tendo ido ao Egito e tendo sido apresentado com recomendaçôes ao rei, tornou-se administrador de todo o país. Antes, os egípcios se ocupavam da agricultura de modo desordenado, pelo fato de o país não ser dividido. Então, os mais fracos eram tratados com injustiça pelos superiores. Ele foi o primeiro a dividir a terra e demarcá-la com fronteiras. Muita terra que era deixada estéril ele tornou cultivada, e algumas das aráveis ele concedeu aos sacerdotes. 3. Ele também inventou as medidas.

E por essas coisas foi grandemente amado pelos egípcios. Casou-se com Assenete, filha do sacerdote de Heliópolis, ${ }^{12}$ a partir da qual gerou filhos. Depois dessas coisas, vieram até junto dele tanto seu pai quanto seus irmãos trazendo muitas propriedades, e foram estabelecidos na cidade do Sol e em Saís. ${ }^{13}$ E os sírios se tornaram numerosos no Egito. 4. [Artápano] diz que esses chamados hermiuth fundaram o templo em Athos e em Heliopólis. Depois disso, morreram José e o rei dos Egípcios.

Então, sendo governante do Egito, José reservou o trigo de sete anos, que era abundante em cada colheita, e tornou-se senhor do Egito. ${ }^{14}$

\section{Fragmento 3 (Praep. EVAng. 9.27.1-37)}

1. Artápano diz em sua obra Sobre os Judeus: Tendo morrido Abraão e seu filho Mempsasthenot, ${ }^{15}$ e igualmente também o rei dos egípcios, a dominação passou para o filho dele Palmanothes. 2. E este agiu mal para com os judeus. Antes, havia edificado Tessan, ${ }^{16}$ e ali estabelecido o templo, e, em seguida, construído o templo em Heliopólis. 3. Ele gerou uma filha, Mérris, a qual ele prometeu em casamento

Faraó a toma como mulher e retribui com notáveis propriedades.

9. O nome não é identificado com o de nenhum rei egípcio conhecido. Pode tratar-se de um nome real, variante de "Faraó", utilizado como se fosse nome próprio (cf. BLOCH: 2009, 26). Pode, de fato, derivar da mesma raiz de Faraó com a adição do nome divino Thoth, mas não necessariamente se trata de um nome ficcional como quer COLLINS: 1985, 897).

10. A permanência de pessoas ligadas a Abraão no Egito não é mencionada ou sugerida pela narrativa canônica. Essa tradição favorece a concepção de uma inter-relação precoce entre judeus e egípcios, e da antiguidade da presença judaica naquelas terras.

11. Sugere-se que o texto foi corrompido por erro de um copista, que teria trocado Ismael por Israel (cf. COLLINS: 1985, 897; BLOCH: 2009, 27). De fato, como os árabes são tidos como descendentes de Ismael já na narrativa bíblica, assim o texto traria um sentido mais harmônico.

12. No texto bíblico, Heliópolis é chamada de On (cf. Gn 41:45).

13. Na narrativa canônica, a localidade em que se instalam Jacó e os seus é chamada Gessen (Gn 45:10).

14. Essa última frase parece mal colocada ao final do trecho, o que suscitou a hipótese de que não se tratasse do texto de Artápano mesmo, mas de 
acréscimo de Alexandre Poliístor (cf. BLOCH:

2009, 29).

15. Visando maior harmonia com a cronologia da narrativa canônica, Collins apresenta a hipótese de que o nome "Abraão" tenha sido colocado no lugar do de "José" possivelmente por Poliístor.

Mempsasthenot seria, nesse caso, nome de um filho de José e Asseneth. Como alternativa, Collins sugere que o correto seria "Jacó" no lugar de "Abraão" e que Mempsasthenot esteja no lugar do nome dado a José pelo Faraó em Gn 41:45, Safanet-Fanec, na Septuaginta, $\psi \mathrm{ov} \theta \mathrm{o \mu} \phi \mathrm{\alpha} \eta \mathrm{n}$ (COLLINS: 1985, 898). Bloch sugere, por sua vez, que o nome seja forjado com

vistas a se assemelhar a nomes faraônicos $(\mathrm{BLOCH}$ : 2009, 29). Essa referência a um filho de nome desconhecido para a narrativa canônica me sugere que o fragmento a respeito de Abraão (se mantivermos o nome como possível aqui) possa fazer parte (ou resumir) um trecho maior da obra de Artápano. Isso nos faria suspeitar de nossa capacidade de reconstrução hipotética da estrutura do texto original.

16. Com Bloch, sigo os manuscritos (e não a correção por te Saïn de Mras), considerando que se trataria de uma transliteração do nome Tanis (BLOCH: 2009, 29). Não obstante, considerando que o nome Tanis (do hebraico צצי tsóan) é transliterado justamente como Tóvis na

LXX, considero tambem plausivel, tanto pelo sentido quanto pela forma, para um certo Khenefres, que era rei das terras além de Ménfis; pois naquele tempo muitos reinavam sobre o Egito. Essa filha, sendo estéril, tomou para si o filhinho de um dos judeus, o qual era chamado Moisés. ${ }^{17}$ (Mas pelos gregos, quando se tornou homem crescido, foi chamado Museu.) 4. Esse Moisés foi professor de Orfeu. ${ }^{18}$ Tendo se tornado homem crescido, muitas coisas úteis transmitiu aos seres humanos, pois inventou as embarcações, máquinas para colocação de pedras, os armamentos egípcios, instrumentos de irrigação e batalha. E ainda dividiu o país em 36 distritos, e a cada uma das províncias definiu o deus ${ }^{19}$ a ser cultuado, bem como as letras sagradas aos sacerdotes, e também que seriam gatos, cães e íbis. E determinou também para os sacerdotes um lugar especial. 5. Ele fez tudo isso com vistas a resguardar firme a monarquia para Khenefres. Pois, antes, estando as multidões desorganizadas, ora expulsavam, ora estabeleciam reis; muitas vezes as mesmas multidões, mas algumas vezes multidões diferentes. 6. Então, por isso, Moisés foi amado pelas multidões e, considerado digno de honra igual a de um deus, pelos sacerdotes foi chamado "Hermes", por causa da interpretação ${ }^{20}$ das letras sagradas.

7. Ao ver a excelência de Moisés, Khenefres o invejou, e procurou destruí-lo por meio de uma causa razoável. ${ }^{21}$ Assim, quando os etíopes fizeram guerra contra o Egito, Khenefres supôs ter encontrado o momento conveniente para enviar Moisés contra eles como general com uma hoste. E designou-lhe uma multidão de agricultores supondo que ele seria facilmente morto pelos inimigos por causa da fraqueza dos soldados. 8. E tendo ido à província chamada Hermopolites com cerca de dez dezenas de milhares de agricultores, ali acampou. E enviou generais que ocupassem a região adiante, os quais obtiveram notáveis vantagens em cada batalha. [Artápano] diz que os Heliopolitas afirmam que essa guerra durou dez anos. 9. Então, os homens de Moisés, por causa do tamanho do exército, estabeleceram uma cidade nesse lugar, e nela erigiram a íbis em dedicação, pelo fato de que ela aniquila os animais que ferem os seres humanos. E a chamaram cidade de Hermes. 
10. É assim, pois, que os etíopes, mesmo sendo inimigos, tiveram afeição por Moisés, de modo que, inclusive, aprenderam com ele a circuncisão das partes pudendas. E não somente eles, mas também todos os sacerdotes. 11. Quando a guerra terminou, Khenefres recebeu Moisés favoravelmente com palavras, enquanto que com ações tramava [contra ele]. Tendo retirado dele as multidões, enviou alguns para as fronteiras da Etiópia com vistas a montarem guarda, aos outros mandou destruírem o templo da cidade de Zeus, construído com tijolos queimados, e construírem outro de pedra, escavando a montanha mais próxima. Ele colocou Nakherota como superintendente da construção.

12. E tendo ido junto com Moisés a Mêmfis, inquiriulhe se havia alguma outra coisa útil aos seres humanos. $\mathrm{E}$ [Moisés] disse: "A raça dos bois, pelo fato de que a terra é arada com eles." E Khenefres, tendo chamado o touro Ápis, mandou as multidóes estabelecerem seu templo, e mandou que, trazendo ali os animais que haviam sido declarados sagrados por Moisés, os sepultassem, querendo ocultar os pensamentos de Moisés. 13. Quando os egípcios mostraram aversão a ele, fez com que os amigos jurassem não anunciar a Moisés a trama arranjada contra ele, e propôs os que haveriam de matá-lo. 14. Como ninguém obedecia, Khenefres censurou Kanethothes, o que mais havia sido incitado por ele. O censurado consentiu com o atentado, para quando tivesse oportunidade.

15. Por esse tempo, quando Mérris morreu, Khenefres incumbiu Moisés e Khanethothes de sepultarem o corpo, depois de levá-lo a um lugar além do Egito, supondo que Moisés seria morto por Khanethothes. 16. Mas enquanto eles estavam a caminho, um dos que sabiam anunciou a Moisés a trama. Guardando-se, sepultou Mérris, e o rio e a cidade que há ali chamou de Meroé. E essa Mérris foi honrada pelos locais não menos que Isis. ${ }^{22}$

17. E Arão, irmão de Moisés, tomando conhecimento da trama, aconselhou o irmão a fugir para a Arábia. Convencido, tendo navegado desde Mênfis pelo Nilo, a sugestão por $\Gamma \varepsilon \sigma \varepsilon \nu$, que Strugnell fez em particular a Collins (COLLINS: 1985, 898). Quanto ao conteudo, a proposta é favorecida por ter sido essa região um centro da presença israelita no Egito conforme o Gênesis. A menção serviria de preparação para o prosseguimento da narrativa, que contaria a libertação das multidões de israelitas do Egito. Quanto à forma, é considerável a possibilidade de confusão entre o tau e o gama no alfabeto grego uncial, o que seria simples e praticamente suficiente para a transmissão do termo Tessam.

17. Não há, como se vê, qualquer menção à perseguição sofrida pelos israelitas. Moisés não é adotado em meio a uma mortandade de infantes. E outros motivos para adoção não são apresentados do lado da família hebreia que abre mão de seu filho, mas somente do lado da filha do faraó, que seria estéril, algo não mencionado, por outro lado, na Bíblia hebraica.

18. A identificação entre Moisés e Museu aparece também em trecho de Numênio citado por Eusébio no mesmo livro (Praep. Evang. 9.8). A proximidade fonética certamente favoreceu a associação entre Moisés e Museu, mas Artápano não quer reproduzir a ordem conhecida da tradição grega, que tem Orfeu como mestre de Museu. Portanto, trata de invertê-la. Colocando Moisés como instrutor de Orfeu, ele faz com que o herói judeu seja responsável não somente 
pela cultura egípcia, como narra, mas também pela grega/helenística.

19. A leitura mais imediata me sugere que Moisés teria definido um deus a ser cultuado em cada localidade. Reconheço, contudo, a partir de nota de Bloch, que poder-se-ia tratar de uma ambiguidade proposital, com "o deus" podendo referir-se ao deus

do monoteísmo judaico exclusivamente (que seria cultuado em cada um dos lugares) ou como na leitura que proponho, um deus para cada $(\mathrm{BLOCH}$ : 2009, 31).

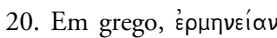
- hermeneían.

21. Com esse desenrolar, que faz lembrar a narrativa canônica de Saul e Davi,

Artápano obscurece da narrativa qualquer referência à deterioração da relação entre os povos (judeus e egípcios) como grupos. $\mathrm{O}$ motivo da saída de Moisés

do centro do poder e do Egito não será mais o sofrimento de seu povo de origem (cf. Ex 2:11), mas uma intriga pessoal.

22. Tal Mérris é desconhecida da história. Ao que parece, Artápano sugere que o nome de Meroé se deve a ela. Nessa localidade, Isis era de fato cultuada, motivo pelo qual a comparação é feita.

23. Localizado imediatamente antes da fuga para a Arábia, o assassínio desse egípcio por parte de Moisés parece reproduzir o narrado em Ex 2:12. O contexto e a cena são, contudo, completamente diferentes. Inclusive, embora do escapou para a Arábia. Mas Khanethothes, inteirado da fuga de Moisés, espreitava como haveria de matá-lo. 18. E, ao vê-lo chegar, desembainhou o sabre contra ele, mas Moisés antecipando-se, segurou sua mão e, desembainhando a espada, matou Khanethothes. ${ }^{23}$ 19. Então, debandou para a Arábia, e habitou junto com Ragüel, o governante daqueles territórios, tomando [como mulher] a irmã dele.

Ragüel quis fazer guerra contra os egípcios, querendo restaurar a Moisés e preparar um reino para a irmã e o genro. Mas Moisés o dissuadiu, pensando em favor dos de seu próprio povo. ${ }^{24}$ Ragüel conteve os árabes de fazerem guerra, mas comandou assaltarem o Egito.

20. Por volta desse mesmo tempo, também, Khenefres morreu, sendo o primeiro de todos os seres humanos a ter elefantíase. Ele caiu nesse sofrimento por ordenar os judeus a se cingirem de veste de linho, e a não se cobrirem com vestimentas de lã, de modo que, estando bem identificáveis, fossem castigados por ele. ${ }^{25}$

21. Moisés fez uma prece a Deus, para que daquele momento adiante os povos cessassem de sofrer males. Quando Deus se mostrou propício, de repente - diz - um fogo se acendeu desde a terra e queimou não havendo no lugar nem madeira nem algum outro tipo de lenha. ${ }^{26}$ Moisés, temendo o que se sucedia, fugiu. Mas uma voz divina disse a ele para fazer guerra contra o Egito e, libertando os judeus, conduzi-los para a antiga pátria.

22. Tendo se enchido de coragem, determinou-se a conduzir uma força bélica contra os egípcios. Mas, primeiro, foi para junto de Arão, o irmão. O rei dos egípcios, inteirado da presença de Moisés, chamou-o para junto de si e inquiriu o motivo de haver ido para lá. Ele disse que o senhor do mundo lhe havia ordenado livrar os judeus.

23. Inteirado, lançou-o na prisão. Mas, ao cair da noite, todas as portas da prisão se abriram por si mesmas, e alguns dos guardas morreram, enquanto outros caíram de sono e tiveram as armas quebradas. 
24. Tendo saído, Moisés foi aos aposentos reais. Encontrando as portas abertas, entrou e, lá dentro, como os guardas estavam adormecidos, despertou o rei. Aterrorizado pelo sucedido, este mandou Moisés dizer o nome do deus que o havia enviado, zombando dele. ${ }^{27} 25$. Inclinando-se para perto do ouvido [do rei], [Moisés] disse. Ao ouvi-lo, o rei caiu afônico, mas ao ser sustentado por Moisés novamente reviveu. ${ }^{28}$

26. Tendo escrito [o nome] em uma tabuinha, a selou, e um dos sacerdotes que tratou com desdém as letras escritas na tabuinha morreu com uma convulsão.

27. E o rei disse que lhe fizesse algum sinal. Jogando o cajado que levava, Moisés fez uma serpente. Enquanto estavam todos assustados, aproximando-se, agarrou-a pela cauda e novamente se fez cajado. 28. Um pouco depois, golpeou o Nilo com o cajado, e o rio se tornou por demais caudaloso e inundou todo o Egito. - Desde então, passou a acontecer a sua "cheia" - Tendo se acumulado, a água passou a feder, os animais fluviais foram dizimados, e os povos pereceram por causa da sede.

29. Depois de terem ocorrido essas maravilhas, o rei disse que depois de uma lua liberaria os povos, caso restaurasse o rio. E Moisés, golpeando a água novamente com o cajado, diminuiu a corrente.

30. Depois disso acontecer, o rei chamou os sacerdotes de além de Mênfis e disse que os mataria e destruiria o templo caso eles também não operassem alguma maravilha. Nesse momento, por meio de alguns encantos e feitiços, fizeram uma serpente e mudaram a cor do rio.

31. Tendo se tornado insolente com o ocorrido, o rei maltratou os judeus com todo tipo de vingança e castigo. Vendo isso, Moisés realizou outros sinais. E golpeando a terra com o cajado, liberou um animal alado para afligir os egípcios, e todos tiveram chagas nos corpos. Os médicos não podiam curar os doentes. Assim, novamente, aconteceu de os judeus receberem suavização no tratamento. ponto de vista cronológico haja alguma relação, do ponto de vista funcional a cena aqui tem uma colocação diferente. No relato do Exxodo, é a morte do egípcio que desencadeia a fuga. Em Artápano, Moisés já está em fuga, por outro motivo, e sendo perseguido pelo egípcio que é assassinado.

24. Essa atitude de Moisés se contrapõe à história narrada por Ápion e Kheremon (cf., de Flávio Josefo, Apion I.264; I.291-292).

25. A punição de um governante por meio de enfermidades terríveis é um tema recorrente (cf. 2Mc 9:9 e At 12:23).

26. No Êxodo, o milagre reside no fato de o arbusto não se queimar. Aqui, no fato de não existir arbusto ou coisa parecida. Um episódio tão presente na tradição hermenêutica judaica não poderia ser mudado por lapso por alguém experiente nos textos dos judeus. Ou Artápano o altera deliberadamente ou o conhece de modo precário. Embora a primeira opção seja bastante plausível, a segunda não é impossível.

27. É difícil compreender como o rei pode estar aterrorizado e, simultaneamente, querer zombar de Moisés (ou do deus de Moisés). Talvez seu terror se deva somente ao fato de Moisés estar ali a despertálo. Ele teme, mas sua posição de poder ainda lhe permite zombar do inferior que lhe oferece ameaça. Moisés havia dito que o "senhor do mundo" 
lhe mandara livrar os judeus. Ele duvida e quer saber quem é o tal "senhor do mundo".

28. Esse é o episódio preservado também por Clemente de Alexandria, que se encontra traduzido em seguida.

29. Aqui se encerra a narração das pragas, que no texto de Artápano não são dez como no Exodo e,

ademais, diferem em

diversos pontos das

descritas no texto canônico.

O terremoto, por exemplo,

é uma novidade muito perceptível acrescentada por Artápano.

30 Esse recurso a versōes (no presente caso, provavelmente ficcionais) transmitidas por habitantes de certos lugares pode ser visto como modo de escrever à maneira da historiografia de Heródoto (JOHNSON: 2004, 98). A primeira versão traz uma explicação

livre de intervenções sobrenaturais, mas ainda assim favorável a Moisés. A segunda, como se verá, reproduz o milagre bíblico de Ex 14, mas não com precisão. Quanto à primeira versão, vale considerar e comparar com Ex 13:18.

31. Se a narrativa canônica permite calcular a idade de

Moisés durante o êxodo em oitenta anos (120 de sua morte menos 40 de sua peregrinação pelo deserto), é inevitável questionar o motivo de Artápano indicar outra idade. Se não tinha conhecimento exato desse dado da tradição canônica, pode ter acrescentado uma idade especifica para simular precisão, e essa
32. E, novamente, Moisés liberou o sapo pelo cajado, e, somando-se a esses, gafanhotos e piolhos. - E por isso também os egípcios dedicaram um cajado em todo templo, e de modo semelhante também para Isis, pelo fato de ser Isis a terra, que liberava as maravilhas quando era golpeada com o cajado. - 33. Como o rei ainda permanecia em sua tolice, Moisés produziu granizo e terremoto durante a noite, de modo que os que fugiam do terremoto eram destruídos com o granizo, e os que evitavam o granizo eram arruinados pelo terremoto. Nessa ocasião, ruíram todas as casas e a maioria dos templos. ${ }^{29}$

34. Por fim, tendo caído nessas desventuras, o rei libertou os judeus. E tendo eles tomado dos egípcios muitos copos, não pouca vestimenta e mais um vasto tesouro, e tendo cruzado os rios da região da Arábia e uma considerável área, chegaram ao Mar Vermelho no terceiro dia.

35. Os Memphitas, então, dizem que Moisés, que era experiente naquela região, aguardando a maré baixa, fez a multidão passar pelo chão seco do mar. Já os Heliopolitas ${ }^{30}$ dizem que o rei saiu em perseguição com uma grande força, também com os animais sagrados, pelo fato de os judeus terem partido tomando a propriedade dos egípcios. 36. E uma voz divina veio a Moisés para que ele golpeasse o mar com o cajado e este se separasse. E, tendo ouvido, Moisés tocou com o cajado sobre a água, e assim o líquido se separou, enquanto a hoste avançou por um caminho seco.

37. Diz que quando os egípcios adentraram e continuavam na perseguição, fogo se acendeu diante deles, e o mar novamente inundou o caminho. $\mathrm{E}$ todos os egípcios foram destruídos pelo fogo e pela cheia do mar. E os judeus, tendo escapado do perigo, passaram quarenta anos no deserto, enquanto Deus fazia chover para eles um tipo de pão semelhante a milhete, com cor muito próxima da de neve. E diz que Moisés era grande, bronzeado, grisalho, de cabelos longos e cheio de dignidade. E realizou essas coisas quando tinha por volta de oitenta e nove anos. ${ }^{31}$ 
Então, Artápano, na sua obra Sobre os judeus registra mesmo para harmonizar com a informação genérica que Moisés foi trancado na prisão por Khenephres, rei dos egípcios, quando pediu que libertasse o povo para fora do e imprecisa que tivesse da tradição judaica.

\section{REFERÊNCIAS}

BARBU, Daniel. Artapan: Introduction historique et historiographique. In: BORGEAUD, Philippe; RÖMER, Tomas; VOLOKHINE, Youri. Intérpretations de Moïse: Égypte, Judée, Grèce et Rome. Leiden: Brill, 2009. p. 1-24.

BLOCH, René; BORGEAUD, Philippe; RÖMER, Thomas; SMYTH, Matthieu; VOLOKHINE, Youri; ZAMAGNI, Claudio. Les Fragments d'Artapan Cités par Alexandre Polyhistor dans la Préparation Évangélique d'Eusèbe. Traduction et Commentaire. In: BORGEAUD, Philippe; RÖMER, Tomas; VOLOKHINE, Youri. Intérpretations de Moïse: Égypte, Judée, Grèce et Rome. Leiden: Brill, 2009. p. 25-39.

COHEN, Shaye J. D.. Was Judaism in Antiquity a Missionary Religion? In: The Significance of Yavneh and other Essays in Jewish Hellenism. Tubingen: Mohr Siebeck, 2010. p. 299-308.

COLLINS, J. J.. Artapanus: translation and introduction. In: CHARLESWORTH, James H.. Old Testament Pseudepigrapha. Volume 2: Expansions of the "Old Testament" and Legends, Wisdom and Philosophical Literature, Prayers, Psalms, and Odes, Fragments of Lost Judeo-Hellenistic Works. New York: Doubleday, 1985. p. 889-903. 
DONALDSON, Terence L. Judaism and the Gentiles: Jewish patterns of Universalism (to 135 C.E.). Waco (Texas): Baylor University Press, 2007.

FELDMAN, H. Louis. Conversion to Judaism in Classical Antiquity. In: Judaism and Hellenism Reconsidered. Leiden / Boston: Brill, 2006. p. 205-252.

GRUEN, Erich S. Heritage and Hellenism: The Reinvention of Jewish Tradition. Berkeley, Los Angeles and London: University of California Press, 1998.

Diaspora: Jews amidst Greeks and Romans. Cambridge, Massachusetts; London, England: Harvard University Press, 2002.

. Rethinking the Other in Antiquity. Princeton and Oxford: Princeton University Press, 2011.

JACOBSON, Howard. Artapanus Judaeus. In: Journal of Jewish Studies, Vol. LVII, No 2. Oxford: Oxford Centre for Hebrew and Jewish Studies: 2006. p. 210-221.

JOHNSON, Sara Raup. Historical Fictions and Hellenistic Jewish Identity: Third Maccabees in its cultural context. Berkeley and Los Angeles: University of California Press, 2004.

WILL, Edouard, ORRIEUX, Claude. "Proselytisme Juif"? Histoire d'une erreur. Paris: Les Belles Lettres, 1992.

Enviado em janeiro de 2014 Aprovado em abril de 2014. 